\title{
THE INFORMATION SOURCES FOR THE COMPANY DECISION MAKING PROCESS BY BUYING NEW COMPANY VEHICLES WITH REGARD TO ELECTRIC VEHICLES
}

\author{
Eva Chlebišová, Jana Kyzeková
}

\section{Klíčová slova:}

Marketingová komunikace, nástroje marketingové komunikace, business-to-business marketing, nákupní chování firem, elektrická vozidla

\section{Key words:}

Marketing communication, marketing communication tools, business-to-business marketing, organisational buying behaviour, electric vehicles

\begin{abstract}
Abstrakt
Dnešní doba je charakteristická výrazně rostoucí výrobou a využíváním automobilů, zvyšováním spotřeby paliv a zároveň významnou změnou klimatických podmínek. Jedním z možných řešení souvisejících ekologických a ekonomických problémů je použití automobilů s elektrickým pohonem. Rozšíření a využití elektromobilů jako prozatím neodzkoušené technologie je nutné podpořit marketingovými aktivitami. Tento článek pojednává o modelu marketingové komunikace na podporu rozšíření elektrických automobilů, který vychází z výzkumu konaného v roce 2010 na českém trhu. Cílem příspěvku je specifikovat a analyzovat zdroje informací a marketingové komunikační nástroje, které členové rozhodovací jednotky firem využívají při rozhodování o nákupu automobilu pro firemní účely a určit vhodné nástroje k podpoře rozšîření elektromobilů ve firmách.
\end{abstract}

\begin{abstract}
The current period is characterized by an exceptionally high increase in production and use of cars, increase of gas consumption and significant changes of climatic conditions. One of the possible ways of solutions, not only environmental but also economic problems, is utilization of electric-powered cars. The enlargement of the electric vehicles use as a new and untested technology market is necessary to be supported by marketing activities. This article offers a model of marketing communication to promote the expansion of electric cars to organizations, based on the marketing research, which was held in the Czech Republic in 2010. The main objective of the article is to specify and analyze information sources and marketing communication tools, which are used by organizational decision making process by vehicle purchase and identify proper tools to promote usage of electric vehicles in organizations.
\end{abstract}

\section{Introduction}

Car ownership brings many benefits to consumers, such as freedom of movement, comfort, speed of transport and others. At the same time with increasing number of car users is growing the air pollution and it leads to changes in climatic conditions. Governments of many states try to solve air pollution problems by different ways - by supporting the production of cleaner fuels, use of catalytic converters, reducing the allowable emissions or promoting the production of alternative sources of propulsion.

One of the possible ways of solutions, not only environmental but also economic problems, is utilization of electric-powered cars, which growth is nowadays supported by the main 
carmakers. The advantages of electric vehicles (EVs) are mostly economic and effective operation and reduction of pollution caused by traffic in towns. Unfortunately these advantages are still contrasting with the high price of EVs given by the price of the batteries and accessibility of recharging infrastructure. Like every other new technology, even this one needs a proper marketing strategy to be fully launched and its advantages could be used.

Research presented in this paper is based on the assumption that existing electric vehicle parameters (operation mode, driving range and price) have complied better with business-tobusiness market requirements so far and therefore is focused on firms (Gärling \& Thøgersen, 2001). Therefore, the main aim of the article is to specify promotion strategy and communication tools, which are used by the members of decision making unit by purchasing and identify proper communication sources of marketing stimuli.

\section{Promotion of Electric Vehicles in the Czech Republic}

In the Czech Republic is now operated around 160 EVs; in 2011 the number increased a half, but it is not very significant in comparison with 173 thousands of conventional vehicles sold the same year. Significant development of EVs diffusion is expected in the 2014, when ŠKODA should come with the new serial produced vehicle. Nowadays has SKODA 15 EVs Octavia Green E Line produced in the Czech Republic in testing, the company plans launch of these vehicles on the 2012/2013, to date was not announced neither promotion strategy nor the price. Other local manufacturers also use the opportunity to innovate in this developing market segment in areas of implementing electric powertrains into common vehicles (e.g. company EVC Group) and developing own powertrains and vehicles (e.g. company Kaipan). Current marketing efforts of car makers and OEMs in this branch are mostly focused on public relations and press releases.

The significant impulse for the diffusion of EVs in Czech conditions is development of the unified charging infrastructure, which is in its beginning. Currently are in operation around 150 charging stations, some of them are private, but the most of them is public, many operated by significant electricity suppliers and distributors, e.g. PRE operates 10 stations, E.ON operates station on the Brno Airport with free charging. The role of energy suppliers is for the Czech automotive E-mobility irreplaceable. The biggest Czech energy supplier ČEZ participate very significantly in projects of electric mobility promotion, creating own program "Elektromobilita" in cooperation with the Ministry of Industry and Business and the Czech Invest. Nowadays, ČEZ operates 25 charging stations and plans to put into operation 200 stations till 2013, also is an author of the three-phase pilot project of testing EVs in local conditions with his partner PEGUEOT (model iON) in innovative systems of smart grids. The project of "Elektromobilia" is involved under the FUTUR/E/MOTION strategy, which is concentrated on overall efficiency and suitability of energy production and distribution using renewable sources.

\section{Specifics of Business-to-Business Marketing Communication}

Communication in business-to-business (B2B) markets differs from communication in consumer markets in accordance to the specifics of decision making process. On consumer markets, it relates not only to pre-buying and buying behaviour, but mostly to general individual motivation for buying a product, which is on $\mathrm{B} 2 \mathrm{~B}$ markets rather rational and result from problems of organisation (Fill, 1995). Moreover, more members of a decision making unit (DMU) usually participate in purchase in the view of order frequency, its financial 
dimension and buying decision complexity. A decision making unit consists of a few individual members who bring, into the rationality of the team decision making process, their personal motives and information based on their own experience, especially if the product is accessible in a consumer market. Motivation of single members and their rate of concern while they make a decision can also vary according to the rate of using the purchased product and the interest in its utility for the firm. Therefore it is necessary in communication to respect personal influences and members' interaction within the unit and emotional motives for decision making about the purchase (De Pelsmacker et al., 2003). The structure and quantity of purchase decision making units differ in individual enterprises according to the type and purchase complexity and according to the size of the enterprise itself as well. The aim of marketing communication in B2B markets is the change of attitudes and opinions of the DMU members with the use of a mixture of personal and impersonal communication tools aimed at an organization purchase unit and target members who have significant effect on final buy decision (De Pelsmacker et al., 2003).

\subsection{Decision Making Process}

The influence of marketing communication on the members of a purchase decision making unit is changing accordingly to the phase of the decision making process. A key role is given to accessibility and achievability of information in the phase of the problem recognition and evaluation of product specification, it means in initial process phases.

In a problem identification phase comes up the awareness of the problem that should be solved by purchase. In the second phase, the phase of product specification, members of a unit specify product characteristics sorting out an organization problem, and thanks to it, they facilitate the consequent supplier choice process. In the supplier choice phase, organizations look for a suitable supplier actively, both from the point of view of quality and parameters of offered products, and from the point of view of possibilities for fulfilling organization requirements by a supplier. In this phase organizations use especially internal information and a market survey to eliminate risks and feelings of some uncertainty caused by new purchase. In the following phase, the evaluation of suppliers' offers is in progress and its time intensity depends on the fact if a supplier is new or present. The final phase of the decision making process is purchase assessment according to fulfilment of determined criteria. In the case that the product or supplier does not satisfy determined organization needs, specification of the product or supplier is usually changed. From the above mentioned facts it is clear that the process of purchase by organizations is a team and interactive process that can be changed by the development of enterprise atmosphere (Fill, 1995).

Fleet car purchase can be done in three ways that influence complexity of a decision making process, and by that even an information need of organizations, it means as a new buy, a modified rebuy, and a routine rebuy (Fill, 1995). A new buy is considered to be as purchase of the product that has not been used in a firm so far or that members of a DMU do not have any experience with, which is not fulfilled in our case. This kind of purchase is very hazard for an enterprise, a decision making process is longer and information demands are high. From this point of view we mark a new buy such decision making that fulfils the above mentioned assumptions. If enterprises buy singly in longer time periods and they always decide about a trademark and car supplier newly, then this purchase is considered to be as a new buy, especially from the point of view of electric vehicle purchase. 


\subsection{Information Sources}

The goal of data gathering in the company is to reduce risks of purchase. Members of a DMU use the enlarged amount of objective resources than consumers. A typical phenomenon is the use of various information sources in different phases of a making decision process. As for Webster (1991) and De Pelsmacker et al. (2003) the information sources can be divided according to the fact whether the source is a person or a group of people or an institution, and whether the source is paid by a seller, it means commercial, or it is completely noncommercial (Figure 1).

\begin{tabular}{|l|l|l|}
\cline { 2 - 3 } \multicolumn{1}{c|}{$\begin{array}{l}\text { Non- } \\
\text { commercial }\end{array}$} & $\begin{array}{l}\text { Interpersonal } \\
\text { Newspapers and independent news } \\
\text { Tests and reviews in journals and hobby } \\
\text { web pages } \\
\text { Professional literature }\end{array}$ & $\begin{array}{l}\text { Firm management } \\
\text { Users of the product in the firm } \\
\text { Co-workers and firm employees } \\
\text { Users of the product outside the firm } \\
\text { (friends and acquaintances) }\end{array}$ \\
\hline \multirow{5}{*}{\begin{tabular}{l} 
Commercial \\
\cline { 2 - 3 }
\end{tabular}} & $\begin{array}{l}\text { Advertising } \\
\text { Catalogues and commercial leaflets } \\
\text { Direct mail } \\
\text { Public relations }\end{array}$ & $\begin{array}{l}\text { Distributors } \\
\text { Personal sale } \\
\text { Exhibitions and trade fairs }\end{array}$ \\
\cline { 2 - 3 } & Importance and credibility &
\end{tabular}

Figure 1. Sources of information and their importance and credibility (modified)

(De Pelsmacker et al., 2003, modified)

The importance for personal contacts is prevailing in B2B markets. Nevertheless, the importance of non-commercial sources (it means independent), both personal and interpersonal, is increasing. We can meet an opinion in literature (Lichtenthal \& Eliaz, 2005; Lichtenthal et al., 2003; De Pelsmacker et al., 2003; Fill, 1995) that interpersonal sources as well as most of commercial sources are used especially at initial stages of a decision making process, when a decision maker does not put much accent on credibility of the obtained information (Table 1).

Table 1. Business media linkages to communication objectives (modified) (Lichtenthal \& Eliaz, 2005; Lichtenthal et al., 2003)

\begin{tabular}{|c|c|c|c|c|c|c|}
\hline Objective & Awareness & Knowledge & Liking & Preference & Conviction & Purchase \\
\hline Publicity & $\bullet$ & & $\bullet$ & & & \\
\hline Advertising & $\bullet$ & $\bullet$ & $\bullet$ & & & \\
\hline $\begin{array}{l}\text { Outdoor } \\
\text { advertising }\end{array}$ & $\bullet$ & $\bullet$ & & & & \\
\hline Direct mail & & $\bullet$ & $\bullet$ & $\bullet$ & & \\
\hline Catalogues & & & $\bullet$ & $\bullet$ & $\bullet$ & \\
\hline Online & $\bullet$ & $\bullet$ & $\bullet$ & $\bullet$ & $\bullet$ & $\bullet$ \\
\hline Trade shows & & & & $\bullet$ & $\bullet$ & $\bullet$ \\
\hline Incentives & & & & $\bullet$ & $\bullet$ & $\bullet$ \\
\hline Telemarketing & & & & & $\bullet$ & $\bullet$ \\
\hline Personal selling & & & & & $\bullet$ & $\bullet$ \\
\hline
\end{tabular}


Towards the higher phases of a decision making process e.g. assessment of offers or supplier evaluation, the accent on personal and internal information sources is increasing. But then, advertising in B2B communication is used especially as a source of building up the interest and awareness. Therefore it is better to use it rather as a bearer of non-tangible and emotional messages. Personal sale and technical documentation is traditionally considered to be the most important tool towards the need of team negotiation (De Pelsmacker et al., 2003).

\section{Research Methodology}

To explore buying behaviour of organisations during buying fleet cars, the questionnaire research was undertaken. A study was focused on data gathering across several sectors from entrepreneurs in Ostrava Region. Because of the innovative technology, the questions were firstly pointed on the influences by purchase of the conventional vehicles followed with the questions regarding attributes and influences by purchase of EVs. The survey questionnaire consisted of a number of closed answers and statements regarding the attitudes of corporate customers to the issues of buying and utilization of EVs. Respondents were asked to evaluate their degree of usage of various information sources and evaluate the degree of agreement with statements regarding the attributes of EVs, which may be main reasons for EV purchase. In these scales was used balanced four-point scale (e.g. the least - the most, strongly disagree - strongly agree). Four points were used for better explanation of possibilities and to eliminate neutral answers.

An e-mail message requesting participation in an academic study of the attitudes to the EVs was sent to 1000 e-mail addresses in two phases in July and August 2010. At the bottom of each e-mail message was the hyperlink, which took each potential respondent to the online survey. The samples of respondents were derived from the publicly accessible company database, using the company sorting and search system. Although only 86 companies out of the initial distribution of 1000 were participated in the survey $(8,6 \%)$, for an online survey these response results are good. The characteristics of survey respondents are shown in the Table 2. The companies are segmented on the demographic basis, for the discussion of proper communication sources is used segmentation from the view of operating variables, which means complexity and type of decision making process.

\section{Table 2. Characteristics of survey respondents}

\begin{tabular}{|lrlr|}
\hline Title of respondent & Share & Sector of industry/business & Share \\
\hline Owner & $61,0 \%$ & Business Services & $26,9 \%$ \\
Executive Director & $12,0 \%$ & Car Services & $10,8 \%$ \\
Department Head & $15,0 \%$ & Manufacturing & $20,4 \%$ \\
Head of Fleet & $7,0 \%$ & Servicing & $11,8 \%$ \\
Other & $5,0 \%$ & Building Industries & $8,6 \%$ \\
Size of company & & Transportation, Logistics & $6,5 \%$ \\
Micro firms (less than 9 employees) & $50,0 \%$ & Catering & $3,2 \%$ \\
Small firms (10 - 49 employees) & $31,4 \%$ & Others & $3,2 \%$ \\
Medium firms (50 - 249 employees) & $12,8 \%$ & End-users & $17,0 \%$ \\
Large firms (250 and more & $5,8 \%$ & Mainly customers & $53,0 \%$ \\
employees) & & & $30,0 \%$ \\
\cline { 1 - 1 } Company Headquarters & & Mainly businesses & \\
\cline { 1 - 2 } Office in Ostrava & $54 \%$ & Equally both types & \\
Office out of Ostrava & $46 \%$ & &
\end{tabular}




\section{Findings}

The realized research reached the results focused on firm preference during purchase of passenger vehicles into the car fleet in a firm, on the way of purchase, and on used information sources in decision making about the purchase.

\subsection{Complexity of Fleet Car Purchase}

The new buy of passenger vehicles into firms mostly (55\%) proceeds singly; firms always specify a vehicle, trademark and supplier. It means that it is always a completely new buy task. On the other hand, $23 \%$ of firms buy new passenger vehicles routinely. Approximately $19 \%$ of firms buy new vehicles into the car fleet in a modified way, which means that in a buying task they only specify either a new supplier or some attributes of a supplied vehicle. Even $67 \%$ of micro firms and $48 \%$ of small firms buy vehicles singly in longer time periods; almost half of medium firms buy feet cars routinely. This result can be explained by the fact that medium firms buy passenger vehicles on the basis of agreements with suppliers; therefore this buy of vehicles is a routine rebuy.

\subsection{Trademark and Engine Type Preference}

The purchasing agents' trademark preference is evaluated in a polarity way $-52 \%$ of respondents do not prefer a trademark and $48 \%$ of respondents prefer a trademark. Those, who prefer a specific trademark, mostly prefer the trademark ŠKODA (44\%). The second most favourite trademark in Moravian enterprises is Volkswagen ( $23 \%)$.

Concerning the size of a firm, more than a half of micro and small firms (56\%), participating in research, do not prefer any trademarks while they buy vehicles in the car fleet. Unlike these firms, most of medium (55\%) and large firms $(67 \%)$ prefer some trademarks. It is caused by the fact that these firms buy passenger cars for the firm on the basis of a long lasting agreement with a chosen seller of the specific trademark and so during each purchase the trademark has already been predetermined. Almost $70 \%$ of firms operating in services (taxi, driving school, car rent) prefer a trademark. We presume that the trademark is important for these kind firms, because it participates on the firm image.

The realized research approached the conclusion that an engine type is more important for firm representatives than a car trademark. Even $70 \%$ of respondents prefer a specific engine type. $67 \%$ of firms prefer a diesel engine, only $13 \%$ a petrol engine and $9 \%$ prefer LPG or CNG. Electric vehicles were not mentioned by any respondents.

\subsection{Information Sources Used in Decision Making}

Respondents evaluated the use of information sources in the scale 1 (the least) -4 (the most) (Table 3). The respondents usually use tests and reviews during decision making about attributes of a purchased vehicle, sellers of vehicles and sellers' web pages. This fact is important for car producers and car sellers as well. Information about electric drive vehicles must be shown in initiated information sources. 
Table 3. Information sources and the ratio of their usage during decision making process

\begin{tabular}{|l|l|l|l|}
\hline & Information source & $\begin{array}{l}\text { Utilization ratio of } \\
\text { sources }\end{array}$ & Average \\
\hline 1. & Tests and reviews & $75 \%$ & 3,0 \\
\hline 2. & Car sellers & $67,5 \%$ & 2,7 \\
\hline 3. & Sellers' web pages & $62,5 \%$ & 2,5 \\
\hline 4. & Car users in the firm & $57,5 \%$ & 2,3 \\
\hline 5. & Hobby web pages & $57,5 \%$ & 2,3 \\
\hline 6. & Journals & $57,5 \%$ & 2,3 \\
\hline 7. & Top firm management & $52,5 \%$ & 2,1 \\
\hline 8. & Newspapers and news & $45 \%$ & 1,8 \\
\hline 9. & Exhibitions and trade fairs & $42,5 \%$ & 1,7 \\
\hline 10. & Shopping departments & $42,5 \%$ & 1,7 \\
\hline 11. & Advertising & $40 \%$ & 1,6 \\
\hline 12. & Leaflets and printed matters & $40 \%$ & 1,6 \\
\hline
\end{tabular}

The utilization ratio of information sources in dependence on a purchase type is given in Table 4.

Tab. 4 Utilization of specific information sources according to the purchase type

\begin{tabular}{|c|c|c|c|c|}
\hline \multirow{2}{*}{ Order } & \multirow{2}{*}{ Information source } & \multicolumn{3}{|c|}{ The way of buying fleet cars } \\
\hline & & Routine & Modified & New, single buy \\
\hline 1. & Tests and reviews & $55 \%$ & $81 \%$ & $85 \%$ \\
\hline 2. & Car sellers & $70 \%$ & $53 \%$ & $56 \%$ \\
\hline 3. & Sellers' web pages & $30 \%$ & $53 \%$ & $59 \%$ \\
\hline 4. & Car users in a firm & $53 \%$ & $29 \%$ & $46 \%$ \\
\hline 5. & Hobby web pages & $10 \%$ & $43 \%$ & $46 \%$ \\
\hline 6. & Journals & $20 \%$ & $60 \%$ & $54 \%$ \\
\hline 7. & Top firm management & $37 \%$ & $40 \%$ & $28 \%$ \\
\hline 8. & Newspapers and news & $10 \%$ & $29 \%$ & $14 \%$ \\
\hline 9. & Exhibitions and trade fairs & $20 \%$ & $21 \%$ & $10 \%$ \\
\hline 10. & Shopping departments & $26 \%$ & $7 \%$ & $14 \%$ \\
\hline 11. & Advertising & $0 \%$ & $27 \%$ & $9 \%$ \\
\hline 12. & Leaflets and printed matters & $0 \%$ & $14 \%$ & $9 \%$ \\
\hline
\end{tabular}

Tests and reviews seem generally to be the most important information source during purchase into the car fleet of firms; it is used by $77 \%$ of enterprises. This source of information use $85 \%$ of firms buying vehicles singly, $81 \%$ of firms buying vehicles in a modified way and $55 \%$ of firms buy routinely. This tool is less used by firms buying routinely, which means the firms with low purchase complexity. ANOVA analysis showed that specific groups of respondents according to the number of employees in a firm evaluated the source "tests and reviews" differently. Pearson Chi-Square coefficient showed that the usage of tests and reviews depends on the number of employees in a firm. This information source is mostly used by $70 \%$ of micro enterprises and $30 \%$ of small enterprises. These two groups have very positive responses. As it has been mentioned above, $67 \%$ of micro enterprises and $48 \%$ of small enterprises buy vehicles singly, newly; complexity and risks of their purchase are higher and from this point of view the tests and reviews can be considered to be quality and objective information sources. 
Car sellers as an information source for decision making are used by $59 \%$ of firms. There is dependence between the information source and the way how passenger cars are bought in a firm (Pearson Chi-Square 0,037). Firms buying routinely use information from car sellers more than it was supposed (a response "the most" - $45 \%$ of firms). Even firms buying singly (56\%) find out information from sellers. This result shows the status of sellers - they are an important information tool for both a group of firms buying routinely and a group of firms buying singly. Sellers' web pages are monitored by about $51 \%$ of firms. In web sites are interested $59 \%$ of firms buying newly, $53 \%$ buying in a modified way, and $30 \%$ of firms buying vehicles into the car fleet routinely. Personal references of car users in firms are used by $44 \%$ of firms. Concerning the way of purchase, they are used mostly by firms buying routinely $-53 \%$ and consequently by firms buying singly $-46 \%$.

Advertising as a used information source statistically depends on the way how a firm buys cars into its car fleet (Pearson Chi-Square 0,033). More than it was expected, firms buying singly do not use advertising. Advertising is more used by the firms that buy cars from time to time and they mostly choose new suppliers. According to the research results advertising is used only by $10 \%$ of firms. The response "not at all" was chosen by $53 \%$ of firms. The response "most of all" did not appear at all. Leaflets and printed matters as an information source are not used by $93 \%$ of firms. Through the correlation analysis we found out that between using leaflets and printed matters $\left(\mathrm{r}^{1}=0,599\right)$ or newspapers and news $(\mathrm{r}=0,533)$ and advertising is positive linear dependence, it means that the more a firm use leaflets/newspapers as an information source about a purchased car, the more they use advertising as well. Strong positive dependence occurs between using leaflets/printed matters and newspapers/news $(r=0,553)$.

\subsection{The Influence of Vehicle Attributes on Purchase}

Zero emission is for $64 \%$ of firms and reduction of noise for $61 \%$ of firms are most crucial for electric vehicle purchase as a fleet car. $92 \%$ of firms consider a crucial criterion during electric vehicle purchase to be low demands on service, $91 \%$ low energy consumption, $93 \%$ high lifespan of a vehicle. Especially these three advantages of electric vehicles should be emphasised within a marketing information campaign. There is statistical dependency between "high lifespan of electric vehicles" and a branch of the firm. More negative responses were among manufacturing and transportation firms. High lifespan of vehicles $(r=0,37)$ has the biggest influence on respondent evaluation, whether they have positive attitude towards electric vehicles. This attribute of electric vehicles can be crucial in persuading customers.

$94 \%$ of firms would welcome state subsidies and tax incentives. The Person Chi-Square coefficient showed that there is dependency between a determined factor, a number of employees and a branch. $83 \%$ of large firms participating in the research, $76 \%$ of small firms, $71 \%$ of micro firms and $36 \%$ of medium firms would be interested in state subsidies and tax incentives promoting the diffusion of electric vehicles. The respondents of transportation firms, $80 \%$ of firms dealing with service, $70 \%$ of building firms, and firms in business service and car service and $61 \%$ of manufacturing firms responded strongly positively. More than half of firms would be interested in operative leasing. Concerning the number of employees, micro firms and medium firms were interested most.

\footnotetext{
${ }^{1}$ Spearman correlation coefficient
} 


\section{Conclusion}

Marketing communication is a key tool for product perception by market, especially for more complex products and services. In case of electric vehicles that goes doubly. At first a customer must learn about a product, which is easier if he is interested in a product himself and actively finds out information.

Our research showed, that the perceived credibility and personality of information sources and communication tools is depending on the complexity of the decision making process. According to the company vehicle purchase, the tests, reviews and personally given information from car sellers may significantly influence type of vehicle, mostly in the case of single or new purchase. These three information sources are very important for micro and small companies, in which is buying process supposed to be done by individuals (owners). From this point of view the small firms specify the demanded vehicle newly and therefore can change former attitudes easier by the personal contact or getting relevant and credible information. Medium and big firms buy the vehicles on the routine or modified basis, using personal information from the car sellers, test and reviews and car users in the company. We can presume that in this target group the impulse for purchase of new electric vehicles has to be based on the effort of personal sale. The research also showed that the usage of advertisement considering the new purchase of electric vehicle is supposed to be inefficient, except the modification of demanded parameters of vehicle. The question for further discussion is that the advertising could change the preferences on motorisation, the switch from conventional vehicle to electric, which is more important parameter than the brand.

The most important communication message, regardless neither the complexity of purchase nor size of the company, is economic efficiency of the vehicle operation, which includes above all low demands on service, low cost operation and high lifespan of the electric vehicle. These communication messages are more important whether the price of the electric vehicles exceeds the price of common vehicles in same user category more than a half. From the engine and brand preferences, we can discuss the brand position as an important factor for company purchase and therefore the communication message. In the small and medium firms the brand is not as important as a motorisation. The reason could be that also the economic efficiency of operation is more important than the position of the brand in the DMU. But, the importance of the brand is not marginal; it can co-create the image of the company or influence the perception of the car quality and reliability. Therefore, the electric vehicles produced e.g. by Volkswagen concern may have better position on the market, especially from the view of medium and big companies and companies offering transport services.

With respect to the research results the change of the attitudes of firm customers must be influenced by the personal communication tools supported by the public relations and press releases. Although a consumer market is regularly informed through the mass media, electric vehicles are considered to be exceptions in a market and therefore needs credible marketing communication to change hesitative perception of firm customers.

\section{Acknowledgement}

The paper is supported by the SGS research project SP/2010106 „Využití klasických nástrojů marketingové komunikace pro podporu elektromobility v Ostravě“. 


\section{Literature:}

[1] DE PELSMACKER, P.; GEUENS, M.; VAN DEN BERGH, J. Marketingová komunikace. Přel. V. Šafaříková. 1. vyd. Praha: Grada Publishing, 2003. 581 s. ISBN 80247-0254-1.

[2] FILL, C. Marketing Communications : Frameworks, theories and applications. 1st edition. [s.1.] : Prentice Hall, 1995. 515 s. ISBN 0-13-150962-4.

[3] GÄRLING, A.; THØGERSEN, J. Marketing of electric vehicles. Business Strategy and the Environment. 2001, vol. 10, no. 1, p. 53-65, ISSN 0964-4733.

[4] GILLILAND, D.I., WESLEY, J. J. Toward a Model of Bussiness-to-Business Marketing Communications Effects. Industrial Marketing Management. 1997, vol 26. s. 15-29. ISSN 0019-8501..

[5] LICHTENTHAL, J.D.; ELIAZ, S. Internet integration in business marketing tactics. Industrial marketing management. 2003, vol. 32, s. 3-13. ISSN 0019-8501.

[6] LICHTENTHAL, J.D.; YADAV, V.; DONTHU, N. Outdoor advertising for business markets. Industrial marketing management. 2005, vol. 35. s. 236-247. ISSN 0019-8501.

[7] CHLEBIŠOVÁ, E.; KYZEKOVÁ, J.; SVOBODOVÁ, H. Marketing Study of the Electric Vehicles' Diffusion. In . Proceeding of the 11th Scientific Conference Electric Power Engineering, EPE'10. 2010. Brno : Vysoké učení technické v Brně. Ústav elektroenergetiky, 2010. ISBN 978-80-214-4094-4.

[8] WEBSTER, F. E. Industrial Marketing Strategy. 3rd edition. New York : John Wiley \& Sons, 1991. 365 s. ISBN 0-471-11989-X.

\section{JEL M31}

\section{Ing. Eva Chlebišová}

Ph.D. student

Marketing and Business Department

Faculty of Economy

VŠB-Technical University of Ostrava

Sokolská 33, 70200 Ostrava

eva.chlebisova.st@vsb.cz

\section{Ing. Jana Kyzeková}

Ph.D. student

Marketing and Business Department

Faculty of Economy

VŠB-Technical University of Ostrava

Sokolská 33, 70200 Ostrava

jana.kyzekova.st@vsb.cz 